\title{
THE STRUCTURE AND FORMULA OF GERONG LYRICS IN THE PRAMBANANRAMAYANA BALLET
}

\author{
Ratun Untoro ${ }^{1)}$, Heddy Shri Ahimsa-Putra ${ }^{2)}$, dan Ida Rochani Adi ${ }^{2)}$ \\ 1) Balai Bahasa DIY dan Mahasiswa Prodi Ilmu-Ilmu Humaniora FIB \\ Universitas Gadjah Mada ${ }^{2}$ Fakultas Ilmu Budaya Universitas Gadjah Mada \\ email: ratunplus@gmail.com
}

\begin{abstract}
Gerong lyrics as the only orality in the Prambanan Ramayana ballet no longer present the story of Rama in its entirety. Although most gerong lyrics contain the scenes, the singers are not always fixated on the lyrics, but prioritize the tones of the chants. This study aims to reveal the structure and formula of gerong chants in the Prambanan Ramayana ballet. It used Levi-Strauss' structuralism theory and Albert Lord's formula theory and employed the qualitative descriptive method. The data were gerong lyrics and their chanting and various supporting orality elements. The results of the study show that the structure in the form of geronginter-lyric relation does not show the Ramayana story plot. In addition, a gerong chant formula is found. The chant formula becomes one of the developments of Lord's formula theory giving priority to the formula of the oral lyrics.
\end{abstract}

Keywords: Ramayana Ballet, structuralism, formula, gerong, chants

\section{STRUKTUR DAN FORMULA LIRIK GERONG DALAM SENDRATARI RAMAYANA PRAMBANAN}

\begin{abstract}
Abstrak
Lirik gerong sebagai satu-satunya kelisanan dalam sendratari Ramayana Prambanan tidak lagi menyajikan cerita Rama secara utuh. Meskipun lirik gerong sebagian besar memuat jalannya adegan, pelantun gerong tidak selalu terpaku pada lirik, tetapi mengutamakan nada lantunannya. Penelitian ini hendak mengungkap struktur dan formula lantunan gerong dalam sendratari Ramayana Prambanan.Teori yang digunakan adalah teori strukturalisme Levi-Strauss dan teori formula Albert Lord. Penelitian ini menggunakan metode deskriptif kualitatif. Data yang digunakan adalah lirik gerong dan pelantunannya serta berbagai elemen kelisanan pendukungnya. Hasil penelitian menunjukkan bahwa struktur yang berupa relasi antar lirik gerong tidak menunjukkan sebuah alur plot cerita Ramayana. Selain itu, ditemukan formula lantunan gerong. Formula lantunan menjadi salah satu pengembangan atas teori formula Lord yang mengutamakan formula lirik lisannya.
\end{abstract}

Kata kunci: Sendratari Ramayana, strukturalisme, formula, gerong,lantunan INTRODUCTION

Dance drama performance is a relatively new genre of performances in Java or, even, in Indonesia. Within the surrounding of Javanese palaces, drama-dance is not known. The staging of drama dances can be found generally in the staging of wayang wong, langendriyan, topeng, and langen(mandra?)wanara (Koentjaraningrat, 1994; Soeharso,1970). Soedarsono and Narawati (2011: 256) explain that the emergence of the new 
genre of drama dances is an impact of the rise of tourism businesses. In responding to tourists' demands to watch traditional performances, tourism providers develop show packages that are suited to the tourists' tastes so that a genre is created which, in other neighbouring countries such as Thailand and Cambodia, is called ballet. It is why there are now in Indonesia the Ramayana Ballet, the Ballet of Bimanyu in Ubud, and others.

There is one important thing to know and study when watching the Prambanan Ramayana show, especially concerning the orality, that is the song sung by wiraswara (male singer) and swarawati (sindhen) (female singer). Spectators (or listeners) are not able to listen to the story very well when listening to the lyrics sung by the wiraswara and swarawati (sindhen). This is because the song lyrics do not combine into complete sentences that will give understanding of the story. It happens that the song lyrics heavily depend on the music consort that accompanies them. Song lyrics are stopped at any word or sentence as soon as the music stops without any obligation for the wiraswara and swarawati (sindhen) to finish their lines. This is one important thing to study in order to help viewers in understanding the story of the show. There is a need in studying how gerong lyrics are connected to the story plot and what the singing formula is like.

Based on the backgrounds presented above, this study is focused on the relation between gerong lyrics and dan formula of the singing of the lyrics in the dance drama. Gerong is the only one form of oral expressions in the dance drama. Two things that are concerned with the gerong lyrics that become the research questions are: (a) How are the gerong lyrics of the Prambanan Ramayana ballet related to the story plot? and (b) What is the structure formula of the singing of the gerong lyrics?
Singing tunes seem not to have interested the attentions of researchers in orality or oral traditions. Oral traditional journals of the 2011 editions published by Slavica Publishers, Inc., Indiana University, present some results of oral tradition studies in the forms of descriptions, transcripsions, and transmissions. Adejunmobi (2011) states performance as a medium for transferring messages. Koerbin (2011) studies about the dominating story of Sultan Abdal in the oral lyrics in Turkey that functions as a means of establishing and legitimating the power of the Sultan. Similarly, Shepherd (2011) uncovers the power of the Shandong story kuaishu as a support to human life spirit. Even though some of them provide the transcripts of the oral tradition, many do not include the tunes por singing as an important and meaningful part of every performance; except for what is done by Adejunmobi (2011). Adejunmobi (2011) appends the recording of the show complete with its singing tunes so that the way of the singing can be presented and becomes an important part of the show. However, Adejunmobi has not analyzed the singing tunes.

Based on the above description of the backgrounds, this study attempts to reveal the relation in gerong lyrics by using Lévi-Strauss structuralism approach that utilizes the relations in elements found as a model to understand a phenomenon. According to Levi-Strauss, a structure of a model is created by an anthropologist to understand or describe a cultural phenomenon (Ahimsa-Putra, 2001: 61; Gidden, 2009: 20). Meanwhile, in order to know a formula of a tune, the formula theory by Lord (1976) can be used.

In reference to structure, Lévi-Strauss (1963: 279) has the following to say. First, a structure has the characteristic of a system; that is, consisting of elements in which a change in one element will bring about changes in the other elements. So, all the 
internal organization and its coherence change. Second, every model is attached on a set of transformation in which all are coherent with one model belonging to the same group. Third, these characteriastics enable one to predict how a model will react if one element changes. Fourth, a model must be constructed in such a way that the way it functions can cover all the facts being observed.

Because this study is based on orality, b3sides orality analysis, it also looks at the formula theory by Lord (1976). Lord (1976:13-14) describes that (1) the reciting of oral poetry in a society in Yugoslavia is spontaneous, recited directly on stage without prompts; (2) Reciting is only based on a plot and theme that are prepared from home; (3) The recitation is dominated by repetition and parallelism; (4) Recitation is enriched with stock epithet, available ready-for-use phrases;

(5) Recitation is constructed of a formula, a word or phrase that is used to fill in a blank space on the subsequent verses that have a specific semantic parallelism. (6) There is a singer-composer-performer unity in the singing; and (7) There is no such term as original or variant for all singing since every singing is original (reproduced all the time).

\section{METHOD}

The study was conducted in Prambanan, at Prambanan Temple to be exact (the locals call it Roro Jonggrang Temple), under the district of Prambanan, Sleman Regency, the Province of the Special Territory of Yogyakarta, boardering with Surakarta Territory of Middle Java Province. There are two stages: open stage and indoor stage. In the outdoor stage, there are two performances: episodic and full story, while the indoor stage only has the full-story performance. It is however true that the performance in the indoor stage is not for the primary data since the main performance in Prambanan is the outdoor performance.
The Open-stage Prambanan opera has its own competitiveness since this is the only one all over the country (Moehkardi, 2011). Meanwhile, the close-door stage performance is a branch 'project' which is not different from Ramayana dance drama in other places such as Inna Garuda Hotel, Ambarukmo Palace Hotel, Pura Wisata Entertainment Centre, and Gabusan Multipurpose Building in Bantul Regency.

One of the data collection techniques consisted of shooting and recording using cameras and audio/video recorders. This was done with the purpose that one was missing from the process being observed and that it could be done repetitively. Besides, interviews were done involving people who were really masters of the research substances. This was done by in-depth interviews to these informants. Another source of data came in the forms of documents, files, and reference materials.

Data analyses were done simultaneously as data were collected during the field work. This was conducted in a flexible doing for different parts of the data collection. Data could be grouped into several categories or, otherwise, one research problem could be attacked by several data sources. It could equally happen where one data source became inspiration for the search for another data source for the purpose of integrative analyses for one particular problem. This way, answers to the research problems could be proposed in accordance with the empirical realities (Miles dan Huberman, 1984). These data collection and analyses were done under the approach of the structural method. Orality supports such as singing tunes and accompanying music were matched with the story plot in every scene. Other than finding the relation between orality (gerong lyrics) and the story plot, formulas were also searched to be compared with the Lord formula. 


\section{RESULTS AND DISCUSSION} Orality in Javanese Dance Drama

Before presenting and analyzing data about the orality in the Ramayana opera of Prambanan, description of orality in Javanese dance drama is given as follows. This is for the significant purpose of knowing the types of orality in Javanese dance drama before existing before the emergence of the dance drama genre. Art performances of dance drama ('sendratari' in the Indonesian language) are of a new genre in Javanese shows, or even in Insdonesia, as has been mentioned above. It seems that the various types of Javanese dance drama have orality of diferrent kinds, including even the decreament of orality. The following table presents the changes in orality in Javanese dance drama.

Table 1 shows that, from the start of the emergence of dance drama, year by year, orality in Javanese dance drama has decreased in types.

Sendratari as a new genre of dance drama that comes out in later years has only one type of orality. The small amount of the orality in the dance drama is felt to decrease the story telling media. This assumption brings to the idea of how gerongan is able to a story telling medium as mentined in the research problems.

Subsequently, to provide answers proposed in the research problems, the following discusses matters related to performance, lyrics, and tune singing in dance dramas, especially that in the sendratari of Prambanan Ramayana. Lyrics and singing in the form of gerongan become the only source of orality; although, in later investigation, other types of singing are found such as ada-ada, gerong, macapat, and sêndhon, sung by penggerong, but they are still categorized as gerongan since they are sung in unison following the rap of the music. The following presents the analysis of the structure of gerong in Prambanan Ramayana dance drama, especially about the relation between the gerong lyrics and the story plot.

Before this, however, in the following is presented the existence of gerong in every scene, part, and episode in the episodic presentation of the Prambanan Ramayana dance drama on the open stage. This is to show that not every scene is accompanied with gerong lyrics and support the assumption that the gerong singing cannot be taken as a lead to listen to the Ramayana story completely.

Tabel 1. Description of orality in Javanese dance drama

\begin{tabular}{|c|c|c|c|c|c|c|c|}
\hline \multirow[t]{2}{*}{ NO } & \multirow{2}{*}{$\begin{array}{l}\text { Dance Drama } \\
\text { (Year of birth) }\end{array}$} & \multicolumn{5}{|c|}{ Orality Type } & \multirow{2}{*}{$\begin{array}{c}\text { Number of } \\
\text { types of } \\
\text { orality }\end{array}$} \\
\hline & & Dialog & $\begin{array}{l}\text { Dialog } \\
\text { with } \\
\text { song }\end{array}$ & Sindhénan & Gerongan & $\begin{array}{l}\text { Dalang } \\
\text { (kandha) }\end{array}$ & \\
\hline 1 & $\begin{array}{l}\text { Wayang Wong } \\
\text { (1756) }\end{array}$ & $\sqrt{ }$ & - & $\sqrt{ }$ & $\sqrt{ }$ & $\sqrt{ }$ & 4 \\
\hline 2 & $\begin{array}{l}\text { Langendriya(n) } \\
(1876)\end{array}$ & - & $\sqrt{ }$ & - & $\sqrt{ }$ & $\sqrt{ }$ & 3 \\
\hline 3 & $\begin{array}{l}\text { Langen } \\
\text { Mandrawanara } \\
\text { (1896) }\end{array}$ & - & $\sqrt{ }$ & - & $\sqrt{ }$ & $\begin{array}{c}\text { Discarded } \\
\text { in } 1960\end{array}$ & $\begin{array}{c}3 \text { to } \\
\text { become } 2\end{array}$ \\
\hline 4 & $\begin{array}{l}\text { Sendratari } \\
(1961)\end{array}$ & - & - & - & $\sqrt{ }$ & - & 1 \\
\hline
\end{tabular}


Table 2. Presence of Gerong Episode I

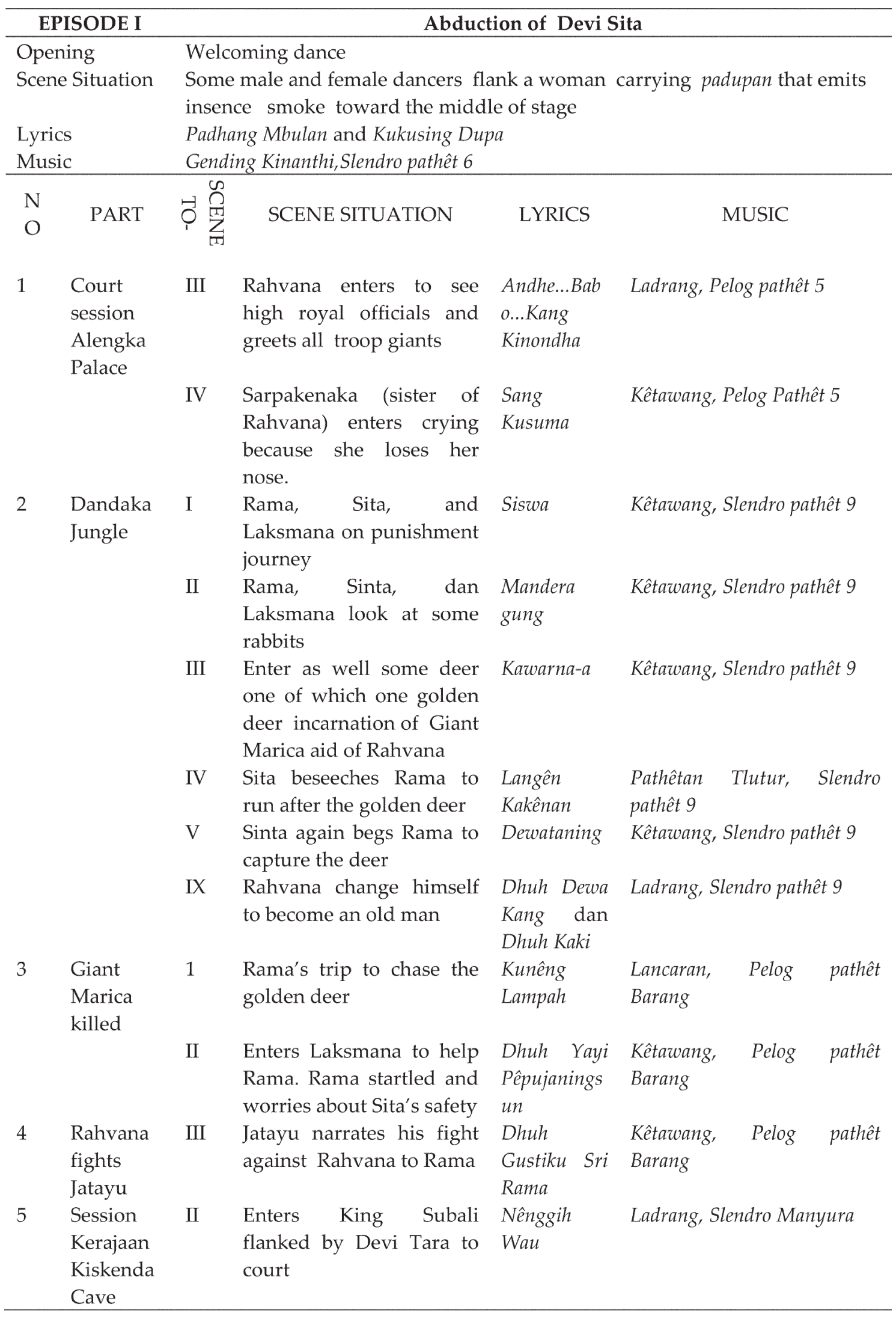


Table 3. Presence of Gerong Epsiode II

\begin{tabular}{|c|c|c|c|c|c|}
\hline \multicolumn{2}{|c|}{ EPISODE II } & \multicolumn{4}{|c|}{ Hanuman Envoy/Hanuman Burned } \\
\hline \multirow{2}{*}{\multicolumn{2}{|c|}{$\begin{array}{l}\text { Opening } \\
\text { Scene Situation }\end{array}$}} & \\
\hline & & \multicolumn{4}{|c|}{$\begin{array}{l}\text { Some male and female dancers flank a woman carrying padupan that } \\
\text { emits insence smoke toward the middle of stage }\end{array}$} \\
\hline \multicolumn{2}{|c|}{ Lyrics } & \multicolumn{4}{|c|}{ Padhang Mbulan and Kukusing Dupa } \\
\hline \multicolumn{2}{|c|}{ Music } & \multicolumn{4}{|c|}{ Gending Kinanthi,Slendro pathêt 6} \\
\hline $\begin{array}{l}\mathrm{N} \\
\mathrm{O}\end{array}$ & PART & ○罗 & SCENE SITUATION & LYRICS & MUSIC \\
\hline \multirow[t]{4}{*}{1} & Court & II & Rama agreed with & & \\
\hline & session & & Sugriva to order & Маеши-еши & \\
\hline & Pancawati & & Hanuman to find & and Wadya & Ladrang, Pelog pathêt 6 \\
\hline & Kingdom & & $\begin{array}{l}\text { Sita carrying a finger } \\
\text { ring as a token }\end{array}$ & Rewanda & \\
\hline \multirow[t]{4}{*}{2} & $\begin{array}{l}\text { Hanuman' } \\
\text { s Trip }\end{array}$ & II & $\begin{array}{l}\text { Hanuman and team } \\
\text { meet Devi }\end{array}$ & & \\
\hline & & & $\begin{array}{l}\text { Sayempraba who } \\
\text { attempts to halt }\end{array}$ & $\begin{array}{l}\text { Andhe-Babo- } \\
\text { Tanpa Kira }\end{array}$ & Kêtawang, Pelog pathêt 6 \\
\hline & & & Hanuman's trip & & \\
\hline & & & $\begin{array}{l}\text { Devi Sayempraba } \\
\text { tricks Hanuman and } \\
\text { friends so that they } \\
\text { get blind }\end{array}$ & $\begin{array}{l}\text { Paduka Kang } \\
\text { Nêmbe }\end{array}$ & Kêtawang, Pelog pathêt 6 \\
\hline \multirow[t]{2}{*}{3} & $\begin{array}{l}\text { King } \\
\text { Sempati } \\
\text { ill }\end{array}$ & II & $\begin{array}{l}\text { Enters King Sempati } \\
\text { who is hurt on his } \\
\text { two wings so that he } \\
\text { cannot fly }\end{array}$ & $\begin{array}{l}\text { Ya Jagad } \\
\text { Pepundhen }\end{array}$ & Ladrang, Slendro pathêt 9 \\
\hline & & III & $\begin{array}{l}\text { Enter Hanuman and } \\
\text { three monkey friends } \\
\text { who are blind }\end{array}$ & Surya Candra & $\begin{array}{l}\text { Kêtawang, Slendro pathêt } \\
9\end{array}$ \\
\hline \multirow[t]{3}{*}{4} & $\begin{array}{l}\text { Garden } \\
\text { Argasoka, } \\
\text { Alengka }\end{array}$ & I & $\begin{array}{l}\text { Devi Sita being } \\
\text { entertained by } \\
\text { Trijatha and royal } \\
\text { maids and servants }\end{array}$ & $\begin{array}{l}\text { Andhe-Babo- } \\
\text { Kang Ginita } \\
\text { and Andhe- } \\
\text { Babo- Kang } \\
\text { Kadriya }\end{array}$ & Ladrang, Pelog pathêt 5 \\
\hline & & II & $\begin{array}{l}\text { Enters Rahvana } \\
\text { courting Sita }\end{array}$ & $\begin{array}{l}\text { Dhuh Yayi } \\
\text { Pêpujaningwan } \\
\left.g^{*}\right)\end{array}$ & Kêtawang, Pelog pathêt 6 \\
\hline & & & $\begin{array}{l}\text { Rahwana gets } \\
\text { impatient and is } \\
\text { going to kill Sita but } \\
\text { prevented by } \\
\text { Trijatha. }\end{array}$ & $\begin{array}{l}\text { Asmoro } \\
\text { Anglimput }\end{array}$ & Asmaradana Macapat \\
\hline
\end{tabular}




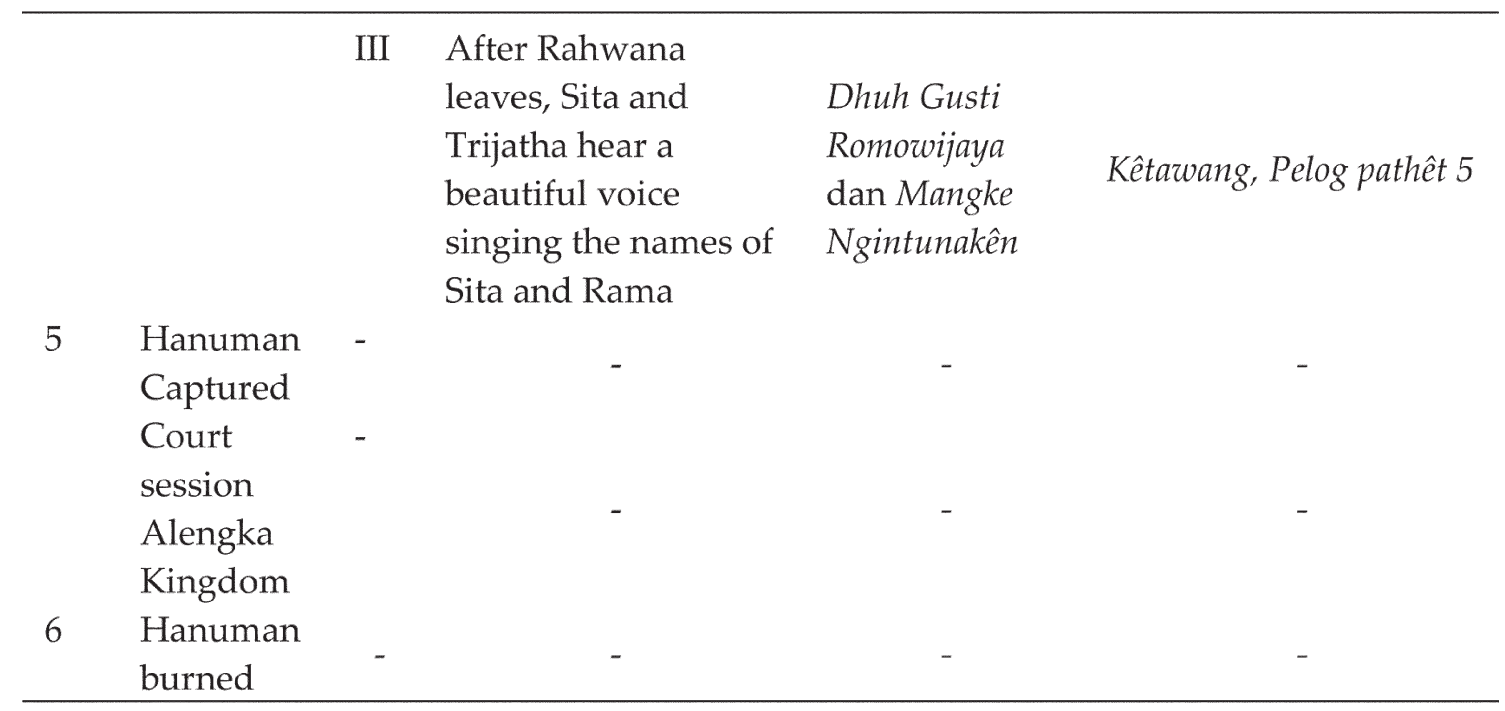

Based on Tables 2 to 5, the presence of gerong in the four episodes cannot be found in every scene, or even in every part. This indicates that some scenes are not narrated or are not uncovered by gerong lyrics so that it is evident that gerong lyrics do not sequentially contain texts about the plot of the story. This fact becomes more evident when a gerong lyric is sequenced and connected with the adjacent other gerong lyrics.

\section{Relation between Gerong Lyrics and Story Plot}

Below is a model of analyzing the relation between a gerong lyric and the subsequent gerong lyric toward two sequential plots showing that there is no relation in the story plot between one gerong lyric and another (taken from dari Episode I, Part III, and scenes I and II)

This part is initialized with scene I, that is Rama's trip in chasing the golden deer, followed by the gerong lyric "Kunêng Lampahnya".

Kunêng lampahnya Sang Bagus

anglimput sesining wukir

samirana tan lumampah

pêtêng jaladhagnampêgi

kadya asung pralampita

tibaning pacoban jati
So was the step of the Handsome covering all the hill the wind not blew dark the clouds came as if giving signals the coming of real test (Narrated, trip of the Handsome (Rama)

(In brief, the contents of the gerong lyrics scene I above tells about Rama's journey that is covered by fog indicating the coming of life challenges).

Telling about the beginning of a new scene, the lyrics above is initialized by the word kunêng that means "as to (the story)". This word is used to separate this verse with the previous lyrics in Part II, scene IX. The lyrics "Kunêng Lampahnya" mark the starting of the conflict signaling that Rama is going to receive life tests. The test is the abduction of Sita as narrated by Laksamana shortly after Rama is able to kill Kala Marica, reincarnation of the golden deer in scene II. However, the gerong lyrics in scene II do not tell about how recounts the disappearance of Sita. The gerong lyrics in scene II, part III is "Dhuh Yayi Pêpujaningsun"

"Dhuh Yayi pêpujaningsun

cahyane pindha kartika ing langit

citrane kasor warangganing swarga

amung kusuma nungkêmi" 
Table 4. Presence of Gerong Episode III

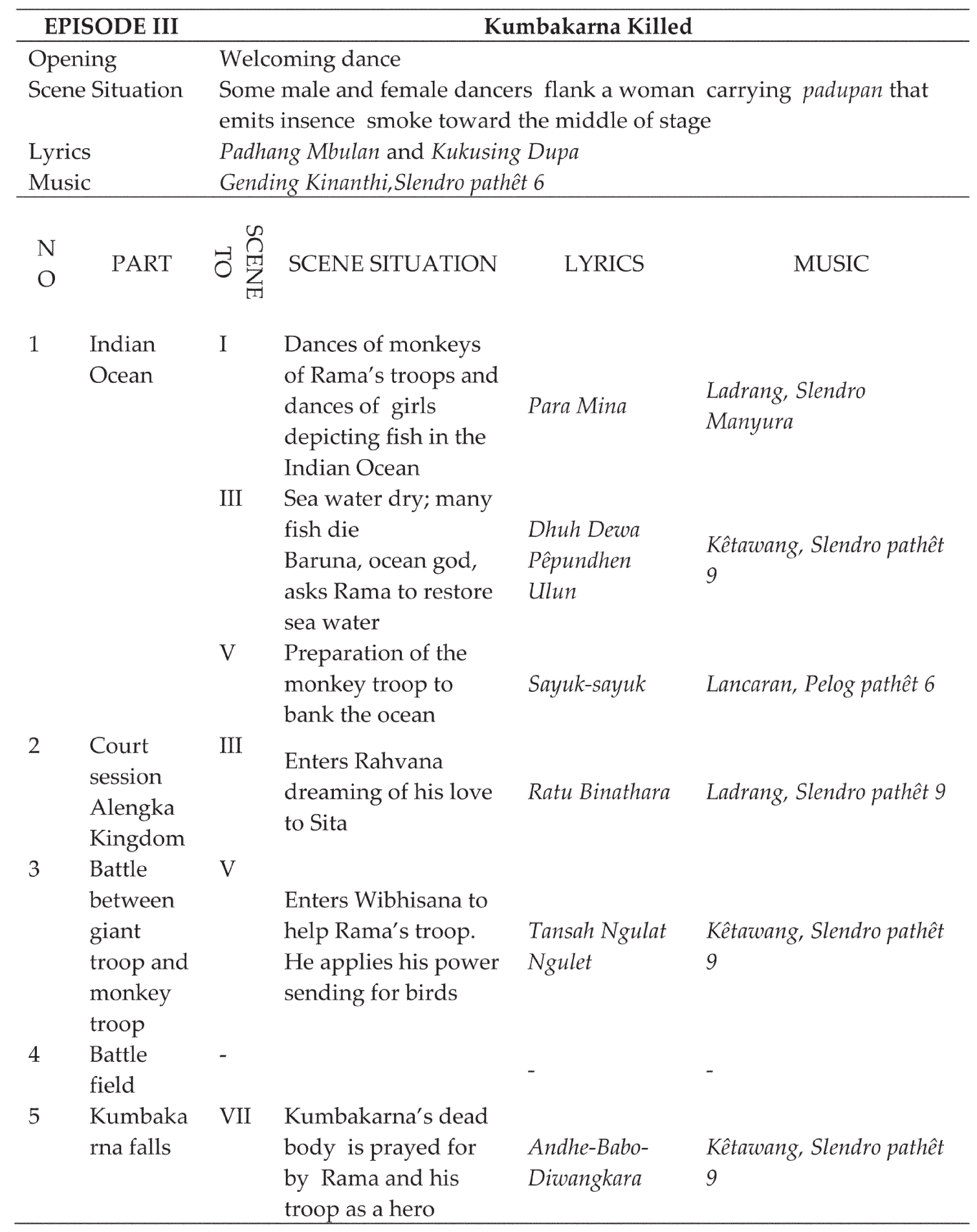

("Alas, my beloved one

the light is like a star in the sky

the image conquers the angel of heaven

only beauty does accompany")
(In brief, the contents of the lyrics in scene II above tells about Rama's lamentation on the beauty of Sita, after knowing the disappearance of Sita). 
Table 5. Presence of Gerong Episode IV

\begin{tabular}{|c|c|c|c|c|c|}
\hline \multicolumn{2}{|c|}{ EPISODE IV } & \multicolumn{4}{|c|}{ Sacred Fire of Devi Sita } \\
\hline \multirow{2}{*}{\multicolumn{2}{|c|}{$\begin{array}{l}\text { Opening } \\
\text { Scene Situation }\end{array}$}} & \multicolumn{4}{|c|}{ Welcoming dance } \\
\hline & & \multicolumn{4}{|c|}{$\begin{array}{l}\text { Some male and female dancers flank a woman carrying padupan that } \\
\text { emits insence smoke toward the middle of stage }\end{array}$} \\
\hline \multirow{2}{*}{\multicolumn{2}{|c|}{$\begin{array}{l}\text { Lyrics } \\
\text { Musicic }\end{array}$}} & \multirow{2}{*}{\multicolumn{4}{|c|}{$\begin{array}{l}\text { Padhang Mbulan and Kukusing Dupa } \\
\text { Gending Kinanthi,Slendro pathêt } 6\end{array}$}} \\
\hline & & & & & \\
\hline $\begin{array}{l}\mathrm{N} \\
\mathrm{O}\end{array}$ & PART & ô & SCENE SITUATION & LYRICS & MUSIC \\
\hline \multirow[t]{3}{*}{1} & $\begin{array}{l}\text { Garden } \\
\text { Argasoka }\end{array}$ & II & Enters Sita in sad face & $\begin{array}{l}\text { Andhe-Babo- } \\
\text { Tan Kagiwang } \\
\text { dan Andhe- } \\
\text { Babo-Tatag } \\
\text { Têguh }\end{array}$ & Ladrang, pelog pathêt 6 \\
\hline & & III & $\begin{array}{l}\text { Enters Rahvana toi } \\
\text { court Sita }\end{array}$ & $\begin{array}{l}\text { Dhuh Yayi } \\
\text { Pêpujaningwan } \\
g \text { *) dan Ratu } \\
\text { Prakosa }\end{array}$ & Kêtawang, Pelog pathêt 6 \\
\hline & & $\mathrm{V}$ & $\begin{array}{l}\text { Trijatha says that } \\
\text { Rahvana is a coward } \\
\text { unless he can really } \\
\text { bring in head of Rama } \\
\text { and Laksmana }\end{array}$ & $\begin{array}{l}\text { Tyas } \\
\text { Kaduwung }\end{array}$ & $\begin{array}{l}\text { Maskumambang; Pelog } \\
\text { pathêt } 6\end{array}$ \\
\hline 2 & $\begin{array}{l}\text { Battle } \\
\text { Field }\end{array}$ & - & - & - & - \\
\hline 3 & $\begin{array}{l}\text { Rahvana } \\
\text { falls }\end{array}$ & $\mathrm{V}$ & $\begin{array}{l}\text { Rahvana's dead body } \\
\text { is prayed for by Rama, } \\
\text { Laksmana, Wibhisana, } \\
\text { and troops }\end{array}$ & Anjarag Mring & Gangsaran, Pelog pathêt 6 \\
\hline \multirow[t]{2}{*}{4} & $\begin{array}{l}\text { Crowning } \\
\text { of } \\
\text { Wibhisana }\end{array}$ & II & $\begin{array}{l}\text { Rama welcomes } \\
\text { Wibhisana who has } \\
\text { worn crown of } \\
\text { Alengka kingdom }\end{array}$ & $\begin{array}{l}\text { Andhe- } \\
\text { Hanarawang } \\
\text { and Andhe } \\
\text { Wus Kadayan }\end{array}$ & Ladrang, Pelog pathêt 6 \\
\hline & & III & $\begin{array}{l}\text { When Rama is about } \\
\text { to embrace Sita, he } \\
\text { suddenly Rama walks } \\
\text { away }\end{array}$ & $\begin{array}{l}\text { Angalumpruk } \\
\text { Tanpa Daya }\end{array}$ & $\begin{array}{l}\text { Sinom Logondang, Pelog } \\
\text { pathêt Barang }\end{array}$ \\
\hline \multirow[t]{2}{*}{5} & $\begin{array}{l}\text { Sinta } \\
\text { Obong }\end{array}$ & I & $\begin{array}{l}\text { Preparation for the } \\
\text { burning ceremony of } \\
\text { Sita }\end{array}$ & Gugur Gunung & $\begin{array}{l}\text { Lancaran;Pelog pathêt } \\
\text { Barang }\end{array}$ \\
\hline & & III & $\begin{array}{l}\text { Sita approaches Rama } \\
\text { and states she is ready } \\
\text { to take her } \\
\text { punishment }\end{array}$ & $\begin{array}{l}\text { Dhuh Dewa } \\
\text { Pêpundhên }\end{array}$ & $\begin{array}{l}\text { Kêtawang, Pelog pathêt } \\
\text { Barang }\end{array}$ \\
\hline
\end{tabular}

LITERA, Volume 16, Nomor 1, April 2017 


\begin{tabular}{|c|c|c|c|}
\hline & $\begin{array}{l}\text { Sita asks permission to } \\
\text { Rama to plunge into } \\
\text { thew fire }\end{array}$ & Sinta Obong & $\begin{array}{l}\text { Kêtawang, Pelog pathêt } \\
\text { Barang }\end{array}$ \\
\hline $\mathrm{V}$ & $\begin{array}{l}\text { Brahma tells Rama } \\
\text { that Sita is pure }\end{array}$ & $\begin{array}{l}\text { Dhuh } \\
\text { Panjilmaning } \\
\text { Wisnu }\end{array}$ & $\begin{array}{l}\text { Kêtawang, Pelog pathêt } \\
\text { Barang }\end{array}$ \\
\hline
\end{tabular}

The gerong lyrics above are in no way directly related to the previous lyrics "Kunêng Lampahnya", although they are adjacent with each other, lyrics in scene I and scene II. There is a jump in the story from the lyrics "Kunêng Lampahnya" to "Dhuh Yayi Pêpujaningsun". The former tells about Rama's journey blanketted in fog when chasing the golden deer; the latter tells about Rama's sadness in thinking of Sita's beauty. This part consists only of two scenes to be continued with part IV.

The example of finding relation among gerong lyrics as described above proves to be effective to answer the research question about the relation between gerong lyrics and the story plot. After looking at the lyrics, relation among lyrics, and narrative media found in the lyrics, it can be stated that the lyrics of the Prambanan Ramayana dance drama of the open stage episodes do not fully contain the Ramayana story. This can mean that the dance drama genre of the sendratari does not rely on orality as the orality medium as it does with the genre of wayang wong, langendriya(n), and langen mandrawanara.

It is worth emphasizing that some gerong lyrics used in the Prambanan Ramayana sendratari, especially of the episodic performances, make use of or borrow from the existing lyric texts that are used in the Javanese music. Not all gerong lyrics congruent with the story of the Ramayana. However, they are agreeable with the scenes and dance movements of the sendratari. Seen from the contents of the gerong lyrics, movement of the story does not run smoothly or, eve, breaks. Moreover, the presence of the gerong lyrics is irregular and uncertain. One is able to understand the story from the episode, part, and scene, but not from the texts contained in the gerong lyrics.

Because relation among gerong lyrics is not reliable for understanding the story plot, this study attempts to follow the story movement route by way of relations among gerong singings which are an unseparable element of the orality in the Ramayana sendratari. Gerong singing is an unseparable part of menjadi gerong lyrics follows the music tune.

\section{Relation between Gerong Singing and Accompanying Music}

Below is presented the comparison between gerong singing tune and accompanying tune area (pathêt) in each part based on the observation results of the Prambanan Ramayana sendratari of the episodic performance.

After ensuring that pathêt is an unseparable element of parts and scenes, an observation is done on the presence of gerong singing. Observation on the comparison between part area tune and gerong singing tune as presented in the tables above shows that gerong singing depends heavily on the pathêt that is being used in the respective part or scene. Often times, gerong singing also becomes a signal of a change of pathêts. At the time when a gerong singing becomes a signal of a music change, its presence is needed as an introduction; although this is not an absolute demand. There are some pathêt changes that do not need gerong signals. It is therefore true that whatever the gerong 
Tabel 6. Comparison between Pathet of Part and Singing Tune

\begin{tabular}{|c|c|c|c|c|c|c|}
\hline $\begin{array}{l}\text { Episode } \\
\text { I } \\
\text { (Pathêt } \\
\text { Area) }\end{array}$ & \multicolumn{6}{|c|}{ Gerong Singing Tune } \\
\hline $\begin{array}{l}\text { Part I } \\
(\text { P1.5) }\end{array}$ & \multicolumn{3}{|c|}{$\begin{array}{l}\text { Singing tune: } \\
\text { Ladrang, (Pl. 5) } \\
\text { [Lyric: Andhe...Babo...Kang } \\
\text { Kinandha] }\end{array}$} & \multicolumn{3}{|c|}{$\begin{array}{l}\text { Singing tune: } \\
\text { Kêtawang (Pl. 5) } \\
\text { [Lyric: Sang Kusuma] }\end{array}$} \\
\hline $\begin{array}{l}\text { Part II } \\
\text { (Sl.9) and } \\
\text { (Sl.M) }\end{array}$ & $\begin{array}{l}\text { Singing } \\
\text { tune: } \\
\text { Kêtawang } \\
\text { (Sl.9) } \\
\text { [Lyric: } \\
\text { Siswa] }\end{array}$ & $\begin{array}{l}\text { Singing } \\
\text { tune: } \\
\text { Kêtawang } \\
\text { (Sl.9) } \\
\text { [Lyric:Man } \\
\text { dero-gung] }\end{array}$ & $\begin{array}{l}\text { Singing } \\
\text { tune: } \\
\text { Kêtawang } \\
\text { (Sl. 9) } \\
\text { [Lyric:Ka } \\
\text { warna-a] }\end{array}$ & $\begin{array}{l}\text { Singing } \\
\text { tune: } \\
\text { Pathêtan } \\
\text { Tlutur, } \\
\text { (SlM) } \\
\text { [Lyric:Lan } \\
\text { n Kakênan] }\end{array}$ & $\begin{array}{l}\text { Singing } \\
\text { tune: } \\
\text { Kêtawang } \\
\text { (Sl.M) } \\
\text { [Lyric: } \\
\text { Dewata- } \\
\text { ning] }\end{array}$ & $\begin{array}{l}\text { Singing } \\
\text { tune: } \\
\text { Ladrang } \\
\text { (Sl.M) } \\
\text { [Lyric:Dhuh } \\
\text { Dewa Kang] }\end{array}$ \\
\hline $\begin{array}{l}\text { Part III } \\
\text { (Pl.br) } \\
\text { Part IV } \\
\text { (Pl.br) }\end{array}$ & \multicolumn{3}{|c|}{$\begin{array}{l}\text { Singing tune: Ladrang (Pl.br) } \\
\text { [Lyric: Kunêng Lampah] } \\
\text { Singing tune: Kêtawang, (Pl.br) } \\
\text { [Lyric:Dhuh Gustiku Sri Rama] }\end{array}$} & \multirow{2}{*}{\multicolumn{3}{|c|}{$\begin{array}{l}\text { Singing tune: Kêtawang (Pl.br) } \\
\text { [Lyric: Dhuh Yayi Pêpujaningsun] }\end{array}$}} \\
\hline $\begin{array}{l}\text { Part V } \\
\text { (S1.M) }\end{array}$ & $\begin{array}{l}\text { Singing tu } \\
\text { [Lyric: Nêr }\end{array}$ & $\begin{array}{l}\text { Ladrang (S } \\
\text { ih Wau] }\end{array}$ & & & & \\
\hline
\end{tabular}

\begin{tabular}{|c|c|c|c|}
\hline Episode & \multicolumn{3}{|c|}{ Gerong Singing Tune } \\
\hline $\begin{array}{l}\text { Part I } \\
\text { (SL.M) }\end{array}$ & $\begin{array}{l}\text { Singing tune: Ladrang, (Sl.M) } \\
\text { [Lyric: Mbalabar Maewu-ewu ] }\end{array}$ & $\begin{array}{l}\text { Singing tune: } \\
\text { [Lyric: Wadya }\end{array}$ & $\begin{array}{l}\text { adrang, }(\text { Sl.M) } \\
\text { Rewanda] }\end{array}$ \\
\hline $\begin{array}{l}\text { Part II } \\
(\text { P1.6) }\end{array}$ & $\begin{array}{l}\text { Singing tune: Kêtawang(Pl. 6) } \\
\text { [Lyric: Andhe-Babo-Tanpa Kira] }\end{array}$ & $\begin{array}{l}\text { Singing tune: } \\
\text { Lyric: Paduka }\end{array}$ & $\begin{array}{l}\text { êtawang (Pl. 6) } \\
\text { ang Nembe }\end{array}$ \\
\hline $\begin{array}{l}\text { Part III } \\
\text { (S1.9) }\end{array}$ & $\begin{array}{l}\text { Singing tune: Ladrang (Sl.9) } \\
\text { [Lyric:Ya Jagad Pepundhên] }\end{array}$ & $\begin{array}{l}\text { Singing tune: } \\
\text { [Lyric: Surya }\end{array}$ & $\begin{array}{l}\text { êtawang (Sl.9) } \\
\text { Indra] }\end{array}$ \\
\hline $\begin{array}{l}\text { Part IV } \\
\text { (P1.5) }\end{array}$ & $\begin{array}{ll}\text { Singing tune: } & \text { Singing tune: } \\
\text { Ladrang(Pl.5) } & \text { Kêttawang (Pl.5) } \\
\text { [Lyric: Andhe- } & \text { [Lyric:Dhuh Yayi } \\
\text { Babo-Kang } & \text { Pêpujaningwang] }\end{array}$ & $\begin{array}{l}\text { Singing tune: } \\
\text { Asmaradana } \\
\text { Macapat } \\
\text { [Lyric:Asmar }\end{array}$ & $\begin{array}{l}\text { Singing tune: } \\
\text { Kêtawang (Pl. 5) } \\
\text { [Lirik: Dhuh Gusti } \\
\text { Ramawijaya and }\end{array}$ \\
\hline
\end{tabular}




\begin{tabular}{|c|c|c|c|}
\hline & $\begin{array}{l}\text { Ginita and } \\
\text { Andhe-Babo- } \\
\text { Kang Kadriya] }\end{array}$ & a Anglimput] & $\begin{array}{l}\text { Mangke } \\
\text { Ngintunakên] }\end{array}$ \\
\hline $\begin{array}{l}\text { Part V } \\
\text { (P1.5) }\end{array}$ & No gerong singing & & \\
\hline $\begin{array}{l}\text { Part VI } \\
\text { (Pl.br) }\end{array}$ & No gerong singing & & \\
\hline $\begin{array}{l}\text { Part VII } \\
\text { (P1.br) }\end{array}$ & No gerong singing & & \\
\hline $\begin{array}{l}\text { Episode } \\
\text { III }\end{array}$ & \multicolumn{3}{|c|}{ Gerong Singing Tune } \\
\hline $\begin{array}{l}\text { Part I } \\
\text { (SL.M ) dan } \\
\text { (P1.6) }\end{array}$ & $\begin{array}{l}\text { Singing tune: Ladrang } \\
\text { (Sl.M) } \\
\text { [Lyric: ParaMina] }\end{array}$ & $\begin{array}{l}\text { Singing tune: } \\
\text { Kêtawang (Sl.M) } \\
\text { [Lyric:Dhuh Dewa } \\
\text { Pêpundhen Ulun] }\end{array}$ & $\begin{array}{l}\text { Singing tune: } \\
\text { Lancaran (Pl.6) } \\
\text { [Lyric: Sayuk-sayuk] }\end{array}$ \\
\hline $\begin{array}{l}\text { Part II } \\
\text { (S1.9) } \\
\text { Part III } \\
\text { (P1.6) }\end{array}$ & \multicolumn{3}{|c|}{$\begin{array}{l}\text { Singing tune: Ladrang (Sl. 9) } \\
\text { [Lyric: Ratu Binathara] } \\
\text { Singing tune: Wêlasan (Pl. 6) } \\
\text { [Lyric: Tansah ngulat ngulet] }\end{array}$} \\
\hline $\begin{array}{l}\text { Part IV } \\
\text { (S1.M) }\end{array}$ & \multicolumn{3}{|c|}{ No gerong singing } \\
\hline $\begin{array}{l}\text { Part V } \\
\text { (Sl.M) }\end{array}$ & \multicolumn{3}{|c|}{$\begin{array}{l}\text { Singing tune: Kêtawang (Sl.M) } \\
\text { Lyric: Andhe-Babo-Diwangkara }\end{array}$} \\
\hline
\end{tabular}

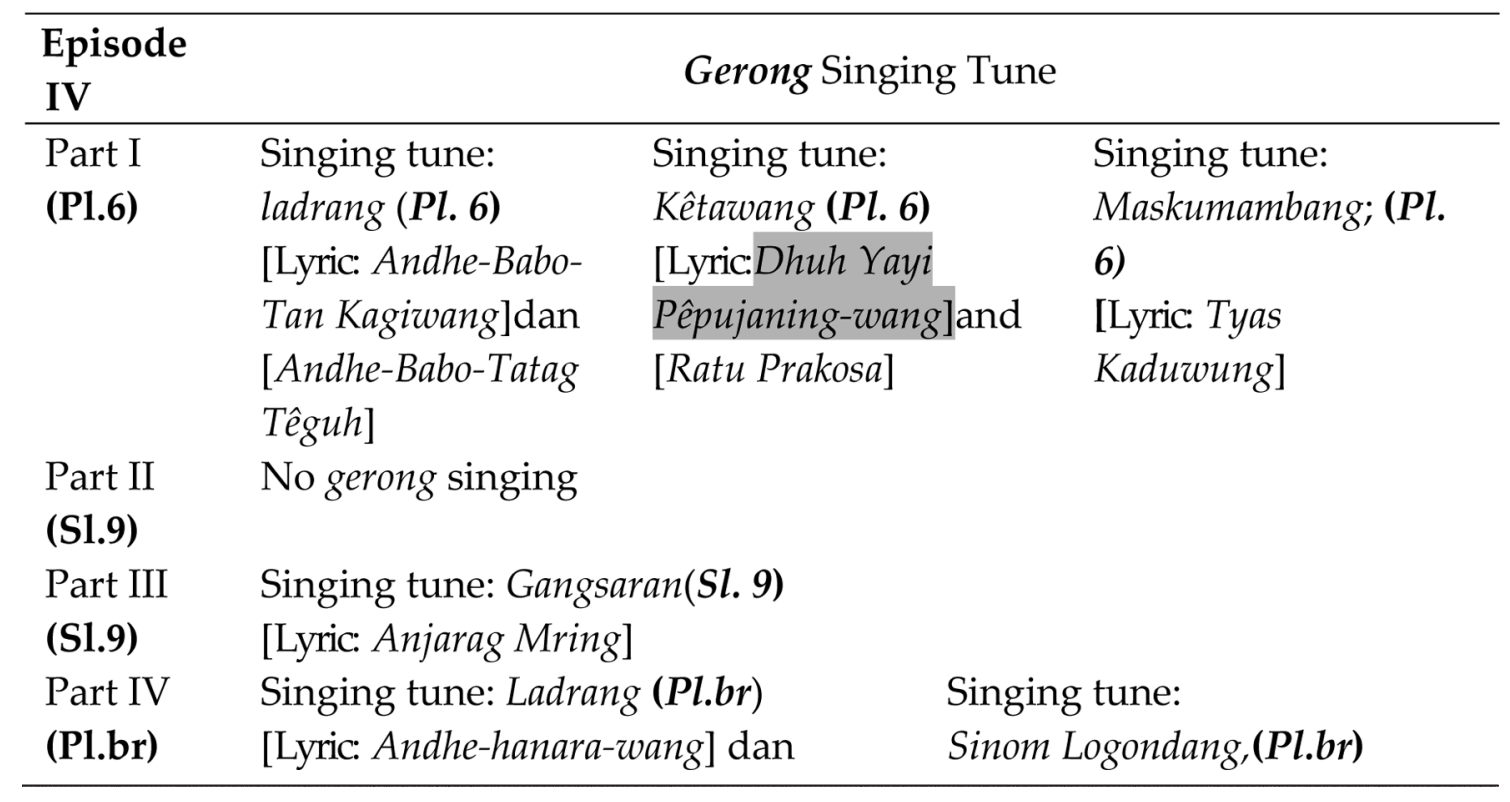




\begin{tabular}{|c|c|c|c|c|}
\hline & \multicolumn{2}{|c|}{ [andhe wus kadayan] } & \multicolumn{2}{|c|}{$\begin{array}{l}\text { [Lyric: Angalumpruk tanpa } \\
\text { daya] }\end{array}$} \\
\hline $\begin{array}{l}\text { Part V } \\
\text { (P1.br) }\end{array}$ & $\begin{array}{l}\text { Singing tune: } \\
\text { lancaran;(Pl.br) } \\
\text { [Lyric: Gugur } \\
\text { Gunung] }\end{array}$ & $\begin{array}{l}\text { Singing tune: } \\
\text { Kêtawang (Pl.br) } \\
\text { [Lyric: Dhuh Dewo } \\
\text { Pêpundhên] }\end{array}$ & $\begin{array}{l}\text { Singing tune: } \\
\text { Kêtawang, } \\
\text { (Pl.br) } \\
\text { [Lyric: } \\
\text { SintoObong] }\end{array}$ & $\begin{array}{l}\text { Singing } \\
\text { tune: } \\
\text { Kêtawang } \\
\text { (Pl.br) } \\
\text { [Lyric: Dhuh } \\
\text { Panjilmaning } \\
\text { Wisnu] }\end{array}$ \\
\hline
\end{tabular}

lyrics are, the singing must be matched with the pathêt that is being used.

\section{Singing Formula in Prambanan Ramayana Sendratari}

As it has been discussed in the previous chapters, the male singers in the Ramayana sendratari rely heavily on the accompanying music either in the pathêt areas (Slendro: nem, sanga, manyura atau Pelog: nem, lima, barang) or in the musical forms (lancaran, srepegan, sampak, ayak-ayakan, and others).

In this case, there are two formulas: music formula and lyric formula. The music formula is ricikan music stroke with certain lengths and impressions or characteristics as has been described by Supanggah (2009:248). The stroke pattern is, among the ethnomusicologists, referred to a formula or pattern. A formula is, among others, a construction or structure of music in the form of lengths of the tune sentence depending on its number of tune raps as has been explained by Hastanto (2009: 50-53). According to Martapangrawit (Supanggah, 2009: 117118), there are 16 music forms of the Javanese music of the Surakarta style; They are (sequenced from the music with the smallest number of tune sentences): lancaran, kêtawang, ladrang, Ayak-ayakan (the Yogyakarta style calls it ayak-ayak), srêpêgan (the Yogyakarta style calls it playon), sampak, kêmuda (the Yogyakarta style calls it srêpêgan kemuda), merong (consisting of: kêthuk 2 (loro or kalih), kêrêp; kêthuk 2 arang (awis);kêthuk 4 kêrêp; kêthuk 4 arang; kêthuk 8 kêrêp, only found in Pelog music); and Inggah forms (consisting of kêthuk 2; kêthuk 4; kêthuk 8; kêthuk 16, only found in Pelog music. However, in the Prambanan Ramayana sendratari, only one agêng music form is found: kinanthi (initiated by lobong music: kêthuk 2 kêrêp), inggah kêthuk 4 kêrêp buka cêluk and seven alit music forms added with palaran and new creation music which by Supanggah (2009: 118) is called music with ambiguous forms.

The second formula is the lyric or cakêpan formula which has the concept of gatra. A gatra is a line in a verse. In its formula, the song Kinanthi, for example, is constructed of 8 gatras or lines. The presence of the lyrics indicates that besides the music formulas, the male singers are also provided with lyric formulas. The two formulas become their main capitals. They must be proficient in the two formulas so that they will able to sing the songs whose lyrics have been assigned to them by the group chairperson, director, or show management. In relation to the study of orality, this becomes interesting since the male singers do not memorize the texts of the songs anymore; but they must master the singing formula. So, for the male singers, mastery of the singing formula/pattern is more important than 
mastery of the texts or lyrics or of words and sentences. This is different from the formula theories proposed by Lord 1976 [1960] who emphasizes the memorizing of words and sentences (texts) using certain formulas. The following presents the combined formula of the music and lyric formulas found in the Prambanan Ramayana sendratari of the episodic show.

In episode I, part I, scene IV of the Ramayana dance drama, there is a gerong singing with the formula of Maskumambang Kêtawang. As it has been discussed before, the formula in one sentence of the kêtawang song consists of 4 gatras (one gong sound) divided into 4 sentences divided into lines. The formula is filled up with the lyrics of the Maskumambang formula that consists of 4 lines with the syllable count and syllable sound: $12 \mathrm{i}, 6 \mathrm{a}, 8 \mathrm{i}, 8 \mathrm{a}$. The kêtawang song has two lines while the Maskumambang formula has four lines; thus the integration. The integration is done in the form of repetition of the kêtawang song into two gong sounds added with ompak-ompak (or just ompak) in the first part as a main song tune before giving the ngêlik (entrance of the gerongan lyrics). The ompak-ompak is functional as a tune leadadded with repetition for the male singers. However, such an ompak formula will not be put up on the frame because it is not directly related to the count of lines in the gerong lyrics. The following is an example of the Maskumambang song titling "Sang Kusuma" found in episode I, part I, scene IV:

Sang Kusuma kararantan kawlas asih

datan antuk karya

kasêmbuh mérang ing galih

dene kasor ing ngayuda

The frame of the singing formula of the Kêtawang Maskumambang looks like the following.

In Figure 1 above, the song gatra that consists of 4 beats is deliberately not displayed since the beats can be lamba or

Figure 1. The Singing Formula of the kêtawang Maskumambang with two gong sounds (symbolized as •) taking "Sang Kusuma" lyric as example found in episode I, part I, scene IV

\begin{tabular}{|c|c|c|c|c|c|c|c|c|c|c|}
\hline \multirow{3}{*}{ Kêtawang } & 1 & 0 & 0 & 0 & 0 & & 0 & 0 & 0 & 0 \\
\cline { 2 - 10 } & 2 & 0 & 0 & 0 & 0 & & 0 & 0 & 0 & $\bullet$ \\
\cline { 2 - 9 } & & \multicolumn{10}{|c|}{} \\
\hline
\end{tabular}

\begin{tabular}{|c|c|c|c|c|c|c|c|c|c|c|c|c|c|}
\hline \multirow{4}{*}{ Maskumambang } & 1 & 0 & 0 & 0 & 0 & 0 & 0 & 0 & 0 & 0 & 0 & 0 & $\mathrm{i}$ \\
\hline & 2 & & & & & & & 0 & 0 & 0 & 0 & 0 & $\mathrm{a}$ \\
\cline { 2 - 10 } & 3 & & & & & 0 & 0 & 0 & 0 & 0 & 0 & 0 & $\mathrm{i}$ \\
\cline { 2 - 10 } & 4 & & & & & 0 & 0 & 0 & 0 & 0 & 0 & 0 & $\mathrm{a}$ \\
\hline
\end{tabular}

\begin{tabular}{|c|c|c|c|c|c|c|c|c|c|c|c|c|}
\hline \multirow{4}{*}{ KêtawangMaskumambang } & Sang & Ku & su & ma & $k a$ & ra & ran & tan & $k a$ & wlas & $a$ & sih \\
\cline { 2 - 12 } & & & & & & & $d a$ & tan & an & tuk & kar & yad \\
\cline { 2 - 11 } & & & & & $k a$ & sêm & buh & mé & rang & ing & $g a$ & lih \\
\cline { 2 - 11 } & & & & & $d e$ & $n e$ & $k a$ & sor & ing & nga & $y u$ & da \\
\hline
\end{tabular}


tamban depending on the lengths of the lyrics (it is, in this case, syllable count).

In episode I, part IV, scene III, there is the singing of kêtawang Mêgatruh. The kêtawang formula consists of two lines in one gong sound while the Mêgatruh lyrics consist of five lines with the order of syllable count and syllable sound: $12 \mathrm{u}$, $8 \mathrm{i}, 8 \mathrm{u}, 8 \mathrm{i}, 8 \mathrm{o}$. The kêtawang song must therefore be repeated three times (three gong sounds) to become six lines. But, then, there are only five lines in the Mêgatruh song; so one line remains. This is resolved by inserting the lyric into the second line (the line with the first gong). The following is an example in the Mêgatruh song titling "Duh Gustiku Sri Rama" found in episode I, part IV, scene III:

Dhuh Gustiku Sri Rama kang ambêg sadhu

Patik bro atur udani

kalamun kusumaningrum

Dyah Sinta sinaut wani

dening Ngalêngka Sang Katong

Below is the formula of the ketawang Mêgatruh singing.

Explanation of the formulas of the kêtawang Maskumambang singing and kêtawang Mêgatruh singing above shows two models of integration between music formulas and song formulas. The first model shows the repetition of music sentences that have a match to the song lyrics. The second shows the repetition of music sentences where one line remains unfilled and the singing begins from the second line. The second model also applies to the singing of kêtawang Mijil.
The song of Mijil has 7 lines so that it needs four repetitions to integrate. Again, one line remains; and the singing of the lyrics begins from the second line. The following is an explanation of another integration model, which is kêtawang Sinom.

The complete data of the formula of the singing of kêtawang Sinom, found in episode II, part IV, scene II refer to Kêtawang Sinom Parijatha, laras Pelog pathêt 6 with the gerong lyric of "Dhuh Yayi Pêpujaningwang". The Sinom song has the formula of 9 lines with the order of syllable count and syllable sound of $8 \mathrm{a}, 8 \mathrm{i}, 8 \mathrm{a}, 8 \mathrm{i}$, $7 \mathrm{i}, 8 \mathrm{u}, 7 \mathrm{a}, 8 \mathrm{i}, 12 \mathrm{a}$. When sung with the accompaniment of the kêtawang music, the sentences must be repeated 5 times ( 5 gong sounds) so that there are 10 music gatras. This singing model is actually similar to that of kêtawang Megatruh and kêtawang Mijil, always leaving out one music line to fill up. For kêtawang Sinom, however, there is a different treatment. The excess of one line in the music is overcome by the splitting of the longest syllable count. In the case of the Sinom song, the last line, which consists of 12 syllables, is split into 2 lines: 4 syllables in the ninth and 8 in the tenth line. This way, there are now five gong sounds in the kêtawang music and all the 10 lines are all filled up. An example of the Sinom song in the frame of the ketawang music can be found in episode II, part IV, scene II as follows.

dhuh Yayi pêpujaningwang Rêkyan Sinta wong akuning tambanana brangtaningwang yen dhatan kapadan ing sih

Figure 2. Formula of the kêtawang Mêgatruh with three gong sounds (symbol: •)

\begin{tabular}{|c|c|c|c|c|c|c|c|c|c|c|c|c|c|}
\hline \multirow{6}{*}{$\begin{array}{l}\text { Kêtawang } \\
\text { Mêgatruh }\end{array}$} & 1 & & & & & 0 & 0 & 0 & 0 & 0 & 0 & 0 & 0 \\
\hline & 2 & $d u h$ & Gus & $t i$ & $k u$ & Sri & $R a$ & $m a$ & kang & $a m$ & $b \hat{e} g$ & $s a$ & $d u 0$ \\
\hline & 3 & & & & & $p a$ & tik & bro & $a$ & tur & $u$ & $d a$ & $n i$ \\
\hline & 4 & & & & & $k a$ & la & mun & $k u$ & $s u$ & $m a$ & ning & rum \\
\hline & 5 & & & & & Dyah & $\operatorname{Sin}$ & $t a$ & si & $n a$ & $u t$ & $w a$ & $n i$ \\
\hline & 6 & & & & & de & ning & $\mathrm{Nga}$ & lêng & $k a$ & sang & $k a$ & $\operatorname{ton} \mathrm{C}$ \\
\hline
\end{tabular}


tan wurung ingsun lalis

kapriye karsanta Masku

datansah ngarsa arsa

Si Rama kang neng wanadri

angur baya manuta marang ragéngwang

The following is the frame of the kêtawang Sinom.

The discussion about the various models of gerong singing formulas describes how repetition or splitting of song lyrics is done to integrate the song into the music that is being played. On the other hand, lyric repetition or splitting is not for the purpose of memorizing or explaining the meaning of the song lyrics or of the story plot. Established song formulas, such as the ones found in the macapat verses may, at any rate, change to match with the music formulas. This is different from Lord (1976:4) who states that a formula is "a group of words regularly used with the same conditions of song types to present a main idea". It is evident, however, that the orality formulas in the Prambanan Ramayana dance drama are no more used to dispatch the story main idea or theme.

Concerning the development of the lyric texts, the gerong lyrics of the Prambanan Ramayana dance drama are prepared long before the staging. The singers have been given scripts that are ready to be sung. Singers do not need to know the texts by heart, but they must master the singing formulas that are used in the songs. This is also different from Lord (1976: 5) who states that the concept of orality is not only understood as oral presentation, but also as oral composition during the performance. In Lord's opinion, during a performance, oral creating also occurs so that it can be said that every performance is a new creation, with a "new" song. A song becomes "more stable" when it is regularly sung (Lord, 1976: 99-101). It is true that the singing formulas used by the Ramayana singers are "stable"; however, not that it is regularly sung. The stability of the singing is, on the other hand, because it uses the singing formulas of the Javanese music pieces that have existed and that are used not only for the Ramayana dance drama but also for various other purposes using the Javanese music. It is true, therefore, that it is the gerong lyrics that is adapted into the available music formulas.

Based on the explanation above, the seven principles in the theory proposed by Lord (1976: 13-14) are not applicable for the orality of the Prambanan Ramayana sendratari genre. The orality theories proposed by Milman Parry during the

Figure 3. Formula of the kêtawang Sinom with five gong sounds (symbol: •)

\begin{tabular}{|c|c|c|c|c|c|c|c|c|}
\hline \multirow{10}{*}{ Kêtawang Sinom } & dhuh & $Y a$ & $y i$ & $p \hat{e}$ & $p u$ & $j a$ & ning & wang \\
\hline & $R \hat{e}$ & kyan & Sin & $t a$ & wong & $a$ & $k u$ & ning \\
\hline & tam & $b a$ & $n a$ & na & brang & $t a$ & ning & wang \\
\hline & yen & dha & $\tan$ & $k a$ & $p a$ & dan & ing & sih \\
\hline & & $\tan$ & $w u$ & rung & ing & sun & la & lis \\
\hline & $k a$ & pri & ye & kar & san & $t a$ & mas & $k u$ \\
\hline & & $d a$ & $\tan$ & sah & ngar & $s a$ & ar & $s a$ \\
\hline & si & $R a$ & $m a$ & kang & neng & $w a$ & $n a$ & $d r i$ \\
\hline & & & & & $a$ & ngur & $b a$ & ya \\
\hline & $m a$ & $n u$ & $t a$ & $m a$ & rang & $r a$ & géng & wang \\
\hline
\end{tabular}

Notes:

The shaded block [ $\square$ ] represents the lyric that is split into two lines. 
1930s succeeded after that by Albert Lord and printed in a book with the title The Singer of the Tales (1976 [1960]) still stumble on orality being a main medium for telling stories. It is different from orality that is found in the sendratari genre which, though identically is used to sing poetry (tunes or songs), it not necessarily a story dispatcher. Orality in the sendratari may or may not be present and is not responsible for telling the story fully.

\section{CONCLUSION}

The analyses on the relations of the gerong interlyrics in the Prambanan Ramayana sendratari of the episodic package in the above section show that the plot of the Ramayana story is not wholly contained in the gerong lyrics. Furthermore, the singing of the gerong lyrics heavily depends on the music formula such that the contents of the gerong lyrics are not as prioritized as the singing tunes that must be a match to the music. This shows that the orality in the Prambanan Ramayana sendratari is not meant to tell the plot of the story but to merely become one of the Javanese identity signals. This identity signals of being Javanese (Indonesian) becomes important when the new genre of Javanese dance drama is to be raise to the globa level. To face the challenge, however, sacrifices are needed. The minimality of the orality in the sendratari is actually a big sacrifice for the Javanese society. Javanese dance dramas, once full with orality containing life teaching and philosophy, must experience cutting and, even, eliminating for the sake of being able to present shows that can be watched by people from outside Java, or Indonesia. The many kinds of orality media such as suluk, kandha, verbal dialogues, and songs that once fully filled Javanese dance dramas have been eliminated and left gerong as the only one remaining in sendratari.
In spite of all of that, however, in a general way, the Prambanan Ramayana sendratari, either its oral element, music, or movement, has reflected the ways of viewing and thinking of the Javanese people about art. The shift from dance dramas to sendratari occurs in the discourse of modernization due to the contestation between tradition and market. Still, this development indicates that the modern Javanese society has contributed in making "instant" culture available for the global world without abandoning local traditions.

The shift of the structure and contexts of the Ramayana in Java, from Serat Rama (Book of Rama) to become Prambanan Ramayana Sendratari, shows the continuity of Javanese cultures past and present. The density of the styling and the symbolicphilosophical contents in the Prambanan Ramayana sendratari in developing cultural products of the modern Javanese society, more particularly Yogyakarta society, are taken not only as an attribute for Yogyakarta as a tourism city, but also, more than that, as an important and represtative icon for the continuity of the Javanese cultures from the past to the present. It is therefore so how every staging of the Prambanan Ramayana sendratari is seen not only as a tourismentertainment activity but also a cultural activity.

This study has also, practically, proposed how creative ideas of traditionbased marketing of art products can be accepted globally so that, in the contexts of macro Indonesia, can be taken as a model for the development of cultural and tourism industries. That way, the cultural wealth of Indonesia is able to compete in this "economy-as-commander" era. This is in agreement with Marsono and Wirjono's (2011) study concerning the positive economic impacts of the presence of the Prambanan Ramayana sendratari. 


\section{ACKNOWLEDGEMENTS}

This article has been taken from the core contents of Ratun Untoro's dissertation titling "Orality in the Prambanan Ramayana Sendratari" that was defended before the Examination Board of the School of Cultural Sciences, Gadjah Mada University, during the closed examination session on June $30^{\text {th }}, 2016$. Appreciation and gratitude go to all the assessors and examiners, most specially to promoters Prof. Dr. Heddy Shri AhimsaPutra, M.A., M.Phil. and copromotor Prof. Dr. Ida Rochani Adi, S.U. from the School of Cultural Sciences, Gadjah Mada University, who have heartily advised on the dissertation writing.

\section{REFERENCES}

Adejunmobi, Moradewun. 2011. "Revenge of the Spoken Word?: Writing, Performance, and New Media in Urban West Africa" dalam Oral Tradition, 26/1 (2011): 3-26. Slavica Publishers, Inc., Indiana University Ahimsa-Putra, H. S. 2001. Strukturalisme Lévi-Strauss, Mitos dan Karya Sastra. Yogyakarta: Galang Press

Gidden, Anthony. 2009. Problematika Utama dalam Teori Sosial, Aksi, Struktur, dan Kontradiksi dalam Analisis Sosial. Yogyakarta: Pustaka Pelajar

Hastanto, Sri. 2009. Konsep Pathêt dalam Karawitan Jawa. Surakarta: ISI Press

Koentjaraningrat. 1994. Kebudayaan Jawa. Cetakan kedua. Djakarta: Balai Pustaka

Koerbin, Paul. 2011. "Pir Sultan Abdal: Encounters with Persona in ALévi Lyric Song" dalam Oral Tradition, 26/1 (2011): 191-220. Slavica Publishers, Inc., Indiana University
Lévi-Strauss, Claude. 1963. Structural Anthropology. Translated from The French by Claire Jacobson. Garden City, New York: Anchor Books, Doubleday and Company, INC.

Lord, Albert B. 1976 [1960]. The Singer of Tales. New York: Atheneum.

Marsono dan Wirjono, 2011. “Kontribusi Pariwisata Budaya dalam Bidang Perekonomian Masyarakat (Studi Kasus pada Candi Prambanan dan Balet Ramayana)" dalam Tourisma, Jurnal Pariwisata No.4 Edisi Januari 2011 hlm. 3-39. Yogyakarta: Program Studi Pariwisata Fakultas Ilmu Budaya UGM

Miles, HB dan Huberman, AM. 1984. Qualitative Data Analysis: A Sources Book of New Methods. Beverly Hills, CA: SAGE publications.

Moehkardi. 2011. Sendratari Ramayana Prambanan, Seni dan Sejarahnya. Jakarta: Kepustakaan Populer Gramedia

Shepherd, Eric. 2011. Singing Dead Tales to Life: Rhetorical Strategies in Shandong Fast Tales" dalam Oral Tradition, 26/1 (2011): 27-70 Slavica Publishers, Inc., Indiana University

Soedarsono dan Tati Narawati. 2011. Dramatari di Indonesia, Kontinuitas dan Perubahan. Yogyakarta: Gadjah Mada University Press

Soeharso. 1970. "Sendratari Ramayana Rara Jonggrang" dalam Seminar Sendratari Ramayana Nasional. Yogyakarta: Panitia Seminar Sendra Tari Ramayana Nasional

Supanggah, R. 2009. Bothekan Karawitan II: Garap. Surakarta: ISI Press 